\title{
Thymic Lobule
}

National Cancer Institute

\section{Source}

National Cancer Institute. Thymic Lobule. NCI Thesaurus. Code C33772.

A structure in a lobe of the thymus $0.5-2 \mathrm{~mm}$ in diameter. The lobule is divided into an outer cortex and inner medulla. Lobules are separated from each other by connective tissue septa, however, the medullary tissue is continuous from lobule to lobule.

Lymphocytes, reticular cells and macrophages are found in the lobules. 